\title{
AN CLINICAL EVALUATION OF THE COMBINED THERAPY FOR MAXILLARY SINUS CARCINOMA WITH IRRADIATION AND THE INTRAARTERIAL INFU. SION OF 5-FU
}

SHUN-ICHI SAKAI, M.D., AKIO NAKAJIMA, M.D., SADAO IKEHATA, M.D., MASAYOSHI OZAKI, M.D., YUTAKA IKEDA, M.D., KUNIYUKI YAMAMOTO, M.D., JUN-ICHI YOSHIDA, M.D. AND KAZUE YANO, M.D. Department of Otolaryngology, Osaka-Kaisei Hospital, Osaka

Therapeutic results of 130 primary cases of maxillary sinus carcinoma from1967 to 1969 and 80 primary cases in 1972 and 1973, were analysed in December 1975. The 2-year and the 5-year crude survival rates for the former were $42 \%$ and $30 \%$, and the 2-year crude survival for the latter was $53 \%$.

The treatment policy over these periods consisted of combined irradiation and intraarterial infusion given as the first step and maxillectomy performed in only recurrent cases.

Therefore, a numerical comparison could be marle between survival rate in the initial combined therapy alone and that in the following maxillectomy. The survival rates of both groups from 1967 to 1969 were almost equal, but, in 1972 and 1973, the therapeutic weight of the initial combined therapy became much heavier than that of the following operation.

A randomized study, carried out from 1967 to 1969 , concerning 25 cases treated by intraarterial infusion of 5-FU alone, 35 cases by intraarterial infusion with other combined drugs and 45 cases by irradiation alone, resulted in the significantly better survival rate and the local nonrecurrence rate of the 5-FU intraarterial infusion group than that of the other groups.

In a trial undertaken in 1972 and 1973,63 cases, $70 \%$ of the total cases, were treated by the combination of intraarterial infusion of 5-FU and irradiation with a total irradiation dose of 5000 rads in 10 fractions during 5 weeks or 3500 rads in 7 fractions during 3.5 weeks. There was no significant difference of the rates concerned between the two groups.

At the same time, therapeutic results of the group in which tumor tissue was removed from the maxillary sinus by curettage were compared with those of group treated without curettage and no significant difference crude survival rates was found between the two groups. However, the 2-year non-recurrence rate by initial treatment combined with curettage was significantly better than that without curettage. This could be evaluated as a worth treatment for preservation of both the figure and the function. On the other hand, this mode of treatment left us such problems as difficulty in following maxillectomy and increase in occurrence of distant metastases.

The authors concluded that in the series of trials for the principle treatment policy of maxillary sinus carcinoma, the best results were obtained by initial treatment by 5000 rads irradiation of Co-60 gamma-ray in 25 fractions during 5 weeks combined with continuous intraarterial infusion of 5-FU in the amount of $2000 \mathrm{mg}$ during 4 weeks, and antrostomy in all cases and curettage, if necessary. The following treatment composed of maxillectomy as a rule and the intracavital or external irradiation additionally depending upon the situation. 
$79 \mathrm{~A}-0671,33399$

\title{
5-FU 動注, 照射併用を基本とした上顎洞癌治療法の評価
}

\author{
大阪回生病院耳礐咽喉科

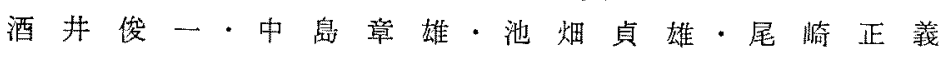 \\ 池田筧・山本邦之. 吉田㴡一. 失野和栄
}

緒言

術前照射が上顎癌の治療にあたつて好結果をもたらす ことは多くの研究者が認めるところであるが,最近では照 射と同時に局所化学燎法齐併用し，小手術を適宜儿組合 わせて根治を仿かる治療方針が定着しようとしているい， ஓ),12)、著者らもその治療方針の正当性を証明しょうとし て昭和 42 年以後の上顠洞癌仁対し，各種薬剤の持続的動 注療法至試みてきた。なかでも5-FU (5-Fluorouracil) 動注併用群においては見る心゙き効果があり9?、昭和47年 以㣪の治療方針には 5-FU 動注併用を基本之するように なつた，小手術として治療開始と同時に上颚洞を開放 し，治療中，治療瑷の排膿と镜察を可能上し，また最近

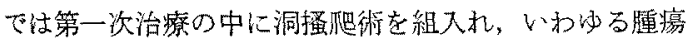
の减量手術が行かれている，一方上顎全摘出術は一次治

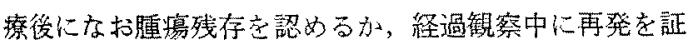
明した場合に限つて施行した。これは一次治療による根 治性を正しく評価すると共に可及的に形態之機能の保存 を志向したものである。

本文に招いてはこれら治療期間中に行われた randomized studyによつて得られた遠隔成績を述べ，5-FU 持続動注照射併用療法の優位性とその限界を評価した。 また二次治療としての上顎全摘出術の占める役割につい ても述べ，す心てを含めた最適治療法を探求しょうとし た，成績そのものは必ずしも满足すべきものではない が，ここで到達した結論は上影洞癌に対する今後の治潦 方針の基本となると思われるので，報告し，諸賢の御批 判を頂きたい。

\section{研究方法}

対象症例は昭和42年 1 月から昭和44年12月までに初部 Lた上頻洞原発癌腫新鮮症例 130 例之, 昭和 47 年 1 月加 ら昭和48年12月までに初診した同症例80例である，各治 潦期間の初为に randomized study の計画がたてられ， 各 trial 群への症例割付壮子内規定された症例を無作為 に割付け(初診の順に配分した)，後日，各群間の症例
構成に有意差がないことを確認した，予め規定した条件

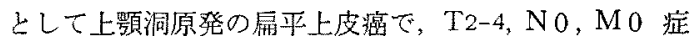
例，また70歳以上，重篤な全身疾患老有するものは除外 した.

昭和42年から 44 年の閒には各種動注薬郕間の差をみる ことを目的とし，trial に使われた薬剤は $5 \cdot \mathrm{FU}$ ，サイク ロヘクサノールサクシネート，アメトーパゾン，ブレオ マイシンであつた，当時法動注併用の可否についてもれ 確定であつたため，対照群として非動注群として照射単 独群を設けた，5-FU 以外の薬凨についてはそれぞれ時 期を变えて行かれて㧍り，各群の例数毛少いが，治療成 紸が芳しくない上判断して打ち切つたものである。実際 の各群症例数洨 5-FU 動注群25例, サイクロへクサノ一 ルサクシネート群18例，アメトヘパゾン群10例，ブレオ マイシン群 7 例，照射単独群45例であつた。これら各群 の症例割付について，局所進展度別，年龄別，性別の検 討がなされたが，いづれも有意差は認められなかつた

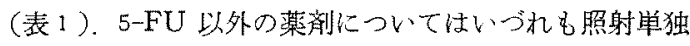
群に比し良好な成績を得ることができなかつたので，本 文においては便宜上, 他剂動注群35例として検討し報告 する.これらの症例の他に除外例として25例があり，治 療期間中の全症例 130 例について検討を要する場合に は、それらのすべてが含まれる。

な㧍この期間の照射法は ${ }^{60} \mathrm{Co}$ r線, 憏状フィルタ一組 合せ直交 2 閏, 1 回 200rad, 铻週 5 回, 総期問 $7 \sim 8$ 週 間, 総線量 2000〜8000rad であつた。

昭和47年と 48年に住 5-FU 持続動注を基本とし，照射 線量を変えてその差をみよらとした， trial 群として ${ }^{60} \mathrm{Co}$ $\gamma$ 線 5000 rad/10 回/5 週群上3500 rad/2回/3.5 週群とが 設けられた。このよらな週 2 回照射法を週 5 回照射法に nominal standard dose (Ellis) を用いて換算すると7000 $\mathrm{rad} / 35$ 回/2 週および5000 rad/25回/5 㥜に相当する，各 群の症例数は 5000 rad 照射群23例ならびに 3500 rad 照射 群26例であり，局所進展度别，年齢別，性別にみた症例 
表 1 昭和42 44年の症例の進展度（初診時）

\begin{tabular}{|c|c|c|c|c|c|c|c|}
\hline & $\begin{array}{ll}\text { 5-FU 陲 注 } \\
\text { 作早 }\end{array}$ & $\begin{array}{c}\text { 他都動 注 } \\
\text { 併 用 }\end{array}$ & $\begin{array}{l}\text { 照 } \\
\text { 単 }\end{array}$ & 独射 & $\begin{array}{l}\text { trial 加 } 5 \\
\text { 除外群 }\end{array}$ & 全 & 例 \\
\hline & 25 & 35 & & 45 & 25 & 130 & \\
\hline $\mathrm{T} 1$ & 0 & 0 & & 0 & 3 & 3 & $2.3 \%$ \\
\hline$T_{2}$ & 10 & 13 & & 10 & 5 & 38 & $29.2 \%$ \\
\hline T 3 & 11 & 17 & & 24 & 15 & 67 & $51.5 \%$ \\
\hline$T_{4}$ & 4 & 5 & & 11 & 2 & 22 & $16.9 \%$ \\
\hline N 1 & 0 & 0 & & 2 & 6 & 8 & $6.1 \%$ \\
\hline $\mathrm{N} 2-3$ & 0 & 0 & & 0 & 1 & 1 & $0.7 \%$ \\
\hline $\mathrm{M} 1$ & 0 & 0 & & 0 & 0 & 0 & $0 \%$ \\
\hline
\end{tabular}

表 2 昭和 $47 ， 48$ 年の症例の推展度（初診時）

\begin{tabular}{|c|c|c|c|c|c|c|c|}
\hline & $\begin{array}{c}\text { 5000rad } \\
\text { 照 射 群 }\end{array}$ & $\begin{array}{l}\text { 3500rad } \\
\text { 照 射 群 }\end{array}$ & 蛋 肥 群 & 非捸爬群 & $\begin{array}{l}\text { trial 加 } 5 \\
\text { 除 外 群 }\end{array}$ & 全 & 例 \\
\hline & 23 & 26 & 25 & 24 & 31 & 80 & \\
\hline $\mathrm{T} 1$ & 0 & 1 & 0 & 0 & 0 & 1 & $1.2 \%$ \\
\hline $\mathrm{T} 2$ & 9 & 7 & 9 & 7 & 8 & 23 & $28.7 \%$ \\
\hline $\mathrm{T} 3$ & 11 & 13 & 12 & 13 & 8 & 33 & $41.2 \%$ \\
\hline $\mathrm{T} 4$ & 3 & 5 & 4 & 4 & 15 & 23 & $28.7 \%$ \\
\hline$N_{1}$ & 0 & 0 & 0 & 0 & 8 & 8 & $10.0 \%$ \\
\hline$N^{2-3}$ & 0 & 0 & 0 & 0 & 4 & 4 & $4.9 \%$ \\
\hline M I & 0 & 0 & 0 & 0 & 0 & 0 & $0 \%$ \\
\hline
\end{tabular}

棒成は雨群間で注ほ均等に分有していた（表2）。この 期間に捛いて trial から除外された症例は31例あり，绦 症例数は80例であつた。

5-FU動注は原則として全例に行われたが，trial から 除外された症例では14例に施行されているので, trial 群と共に計63例（79\%）の症例に5-FU 動注が行われて いる。その総注大量は $2000 \mathrm{mg}$ ない $2500 \mathrm{mg}$ であり， なる心゙く照射期間中持続的にポータブル動注ポンプによ つて注入された。この時期の症例では相当数において上 顎洞の择爬術を照射期間中に1〜2度行つた。もし腫瘍 が舅腔側壁点めるものでは，乙れを划除し，いかゆる Denker 式手術圭行つた日のもある，trial として治療し た49例中盗爬術を行つたものは25例，搔爬術を行わなか つたものは24例となり，てれらはほぼ半数づつ 5000 rad 照射群と3500rad 照射群とに所属するよ5に配責した。 trial 除外群の31例中でも蛋爬街を行つたものが7例あ り，この腈期の全例に対する搔爬術施行菜は40\%であつ t.

一次治療終了後約 1 力月の時点で組織検查を行い, 腫

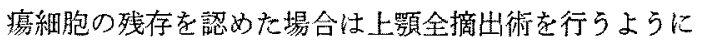
した，組織検査で腫湯細胞を認めなければ，そのまま定 期的観察を続け，もし再発齐確認すれば，ただちに手術 を施行寸る万針で臨んだ，昭和42年から44年の全症例 130例中，上顎全摘出術を施行された症例は57例であり， そのうち54例までは治療開始より 1 年以内に行われてい 万、また昭和 47,48 年の全症例80例中, 昭和50年末まで に行われた上顎全摘出術は20症例であり，その5ち17例 は治撚開始 1 年以内に行われている。

再発に際し上顎全摘出術安行い得なかつたもの，また は街後再発を来したものに関しては，症例ごとに治療が なされたが，小線源による腔内照射，再度外部照射など を行つた場合が多かつた。项部転移に対して项部郭清術 で臨むことを原則としたが，照射を行つた埸合もある。

成 
表 3 昭和42〜44年の全䇥例について 上顎全摘出術有無别にみた粗生存率

\begin{tabular}{|c|c|c|c|c|c|c|}
\hline & I & 年 & 年 & 年 & 年 & 年 \\
\hline 一次治㵔のみで & 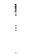 & $45 / 74$ & $27 / 72$ & 2572 & $22 / 72$ & 20,170 \\
\hline 全摘は行わず & & 0.61 & 0.38 & 0.35 & 0.31 & 0.28 \\
\hline 同上の全例に & & 45130 & 27,130 & $25 / 130$ & $22 / 130$ & $20 / 130$ \\
\hline 対与召率 (A) & & 0.35 & 0.20 & 0.19 & 0.17 & 0.15 \\
\hline 二次治療として & 1 & $46 / 56$ & $28 / 58$ & $23 / 58$ & $22 / 58$ & $19 / 58$ \\
\hline 全摘を行つた & & 0.82 & 0.48 & 0.40 & 0.38 & 0.33 \\
\hline 同上の全例心 & & 46130 & $28 / 130$ & $23 / 130$ & $22 / 130$ & $19 / 130$ \\
\hline 対与 る率 (B) & & 0.35 & 0.22 & 0.18 & 0.17 & 0.15 \\
\hline 台計 $(A+B)$ & & $\begin{array}{l}91 / 130 \\
0.70\end{array}$ & $\begin{array}{c}55 / 130 \\
0.42\end{array}$ & $\begin{array}{c}48 / 130 \\
0.37\end{array}$ & $\begin{array}{c}44,130 \\
0.34\end{array}$ & $\begin{array}{c}39 / 130 \\
0.30\end{array}$ \\
\hline
\end{tabular}

表 4 昭和 $42 \sim 44$ 年の全症例につい下 上顎全摘出街有無別にみた局所制御率

\begin{tabular}{|c|c|c|c|c|c|}
\hline & 1 年 & 年 & 年 & 年 & 5 \\
\hline 一次治潦のみで & $33 / 69$ & $27 / 64$ & $24 / 61$ & $19 / 58$ & $19 / 58$ \\
\hline 全摘は行わず & 0.48 & 0.42 & 0.39 & 0.33 & 0.33 \\
\hline 同上の全例に & $33 / 121$ & $27 / 113$ & $24 / 110$ & $19 / 106$ & $19 / 105$ \\
\hline 対する率(A) & 0.27 & 0.24 & 0.22 & 0.18 & 0.18 \\
\hline 二次沿療しして & $32 / 52$ & $23 / 49$ & $23 / 49$ & $21 / 48$ & 10.47 \\
\hline 全摘を行つた & 0.62 & 0.47 & 0.47 & 0.44 & 0.40 \\
\hline 同上の全例に & $32 / 121$ & $23 / 113$ & $23 / 110$ & $21 / 106$ & $19 / 105$ \\
\hline 詨する率 (B) & 0.26 & 0.20 & 0.21 & 0.20 & 0.18 \\
\hline 合計 $(A+B)$ & $\begin{array}{c}65 / 121 \\
0.54\end{array}$ & $\begin{array}{c}50 / 113 \\
0.44\end{array}$ & $\begin{array}{c}47 / 110 \\
0.43\end{array}$ & $\begin{array}{c}40 / 106 \\
0.38\end{array}$ & $\begin{array}{c}38 / 105 \\
0.36\end{array}$ \\
\hline
\end{tabular}

各群について粗生存率を求为, そのうち一次治療の欢 『上頻全摘出術を施行しなかつたものと，二次治潦とし て上䫚全摘出術を施行したものとに分けて粗生存率を算 出した。京た一次治療のみで生存しているもの上，二次

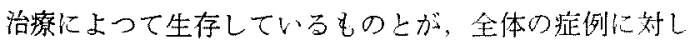
て占める百分率を求め，それ艺肌に粗生存率に寄与する 役割について検討した。

著者らの治療の trial が原発果に対するむのであり， 局所治療であるため，その成績をもつ代ら局所制御に限 つて論じることも意味がある。そのために各群の局所制 御率を求めたが，そのうち一次治療のみによつて局所非 再発を得た率上，二次治療上して上䀎全摘出術を施行し て局所を制御したものの率上を求めた。 をた一次治療に
よる制御数上，二次治療による制御数とが，全症例数に 対して占好百分率を求め，そ机それの局所制御率に等 与する役割についても検討した，局所制御率は粗生存率 上異り，その母数が年々減少する可能性がある。なぜな ら，転移のため死亡したむの，他の疾患のため死亡した もの，追跡掵查を行い得就かったの（生存は判ってい ても局所快態不明の場合がある)などでは，その最終郝 点まで注局所再発を認内ていないが，その得の局所状沉

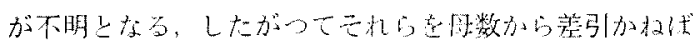
ならない。

まず昭和42年〜44年の全例 130 例について上記の方法 によって粗生存率上局所制御率求好西上表了度らびに 表4のよらになる。亦たこ机ら老グラフに表わすと図1 

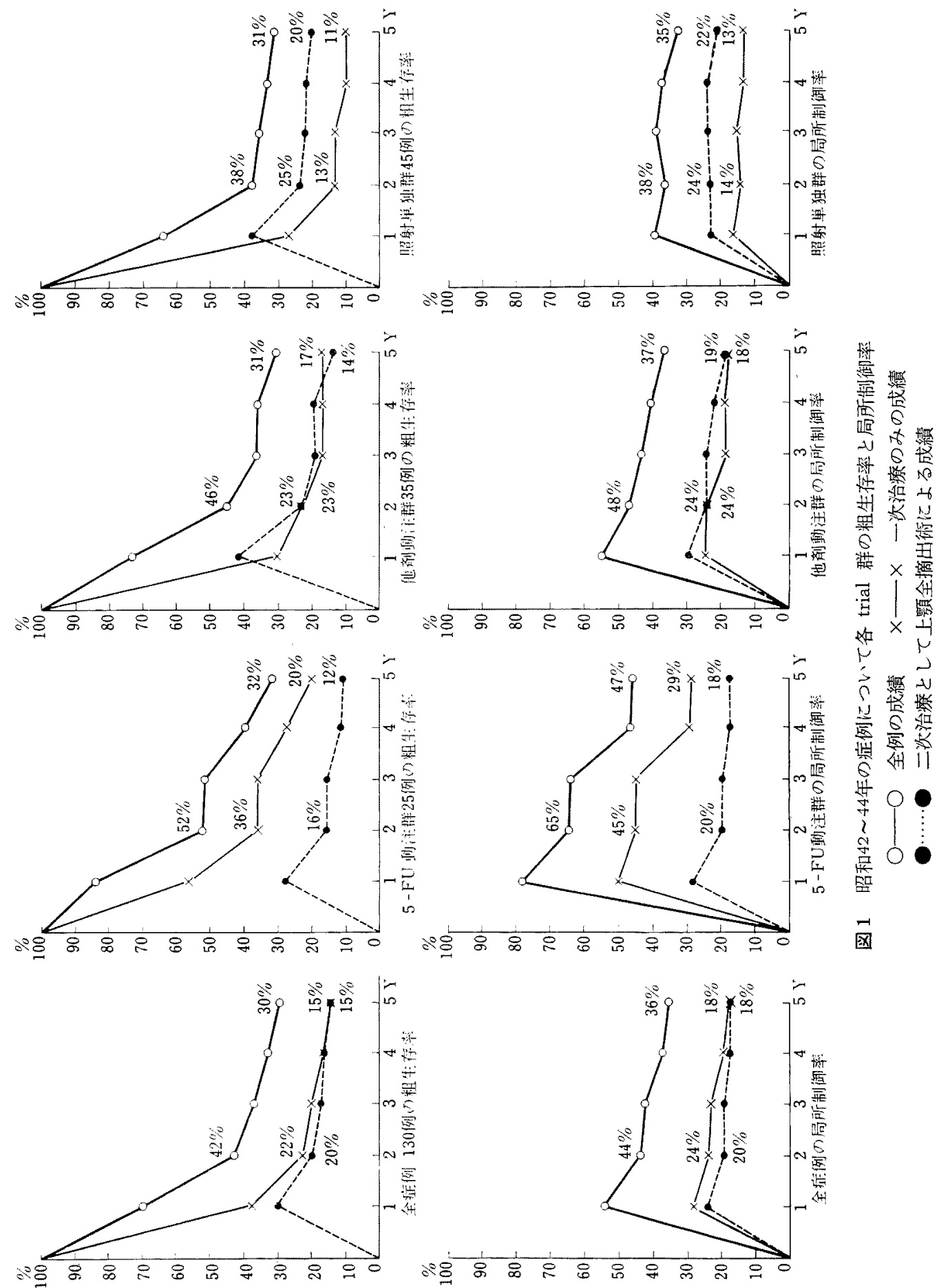

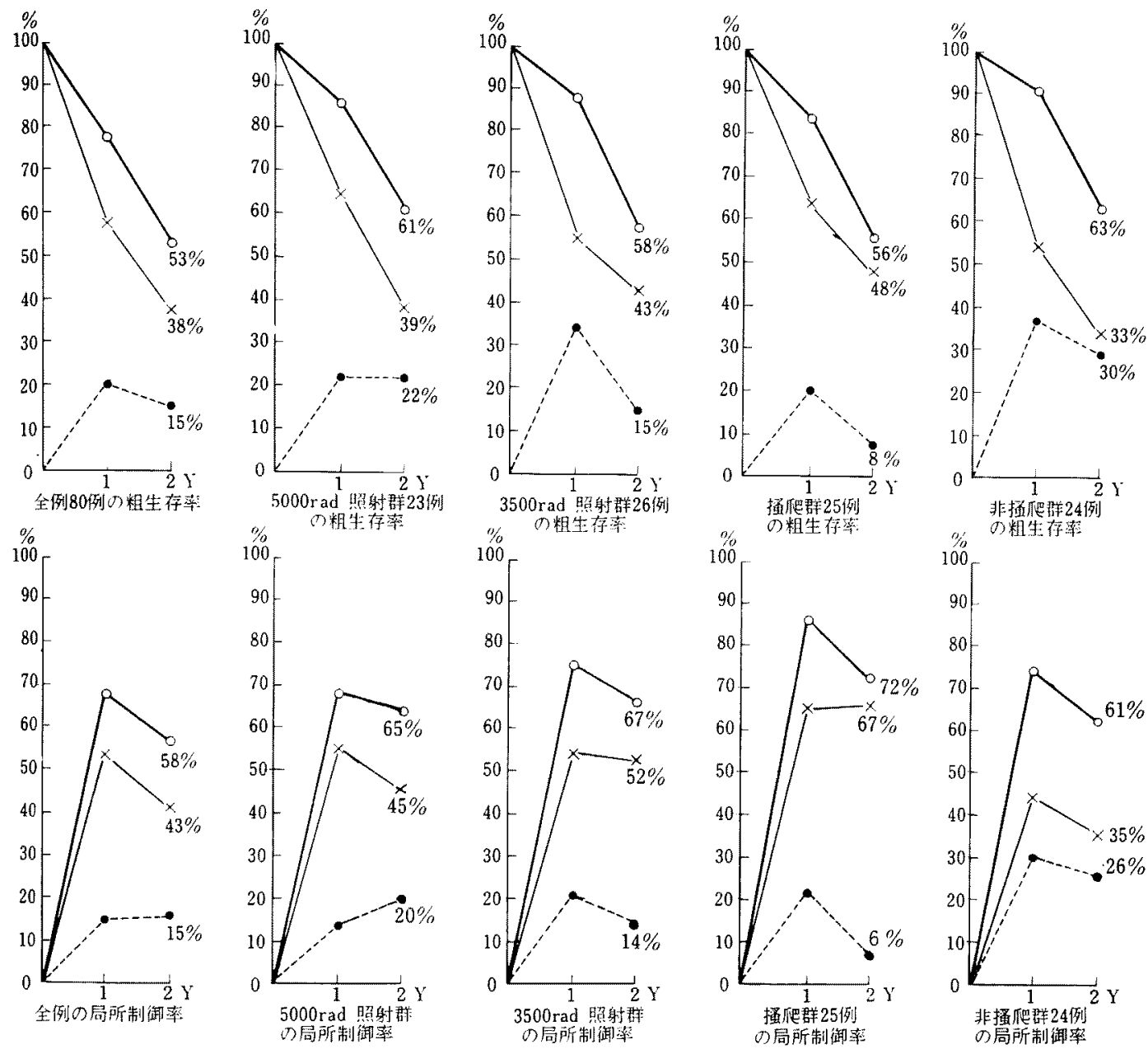

图 2 昭和 $47 ， 43$ 年の症例について各 trial 群の粗生存率上局所制御率 $\bigcirc$ - $\bigcirc$ 全例の成績, $\times$ 一 $\times$ 一次治療のみの成續, 上類全摘出術に上る成績

が得られる。全体の5 年粗生存率は30\%，そのうち一次 治療のみで 5 年生存したものは15\%占め, 残りの $15 \%$ は二次治療として上顎全摘出術を行つたものである。す なわちここでは一次治療と上顎全摘出術との役割がほぼ 等しかつた。局所制御率でみると 5 年成績 $36 \%$ \%゙ある が，そのうち一次治療心上るもの18\%，上頭全摘出術儿 よるもの18\%という結果が得られた。

つぎに各 trial 群について同様の計算方法によつて粗 生存率々局所制御率を求め大。個々の症例数は省略し， 結果をグラフに示すと図 1 となる。5-FU 動注併用群の 5 年粗生存率は $32 \%$ ，局所制御率は $47 \%$ ，他の群に比
し大差がないが、その2年粗生存率は $52 \%$ ，同所制御率 65\%と，他群に比し有意差をもつて好成績であつた。 たそ机登机の群仁扮いて，」频全摘出術の粗生存率上局 所制御率上への寄与率を見ると, 5-FU 動注群は他の群 に比し小さいのである。す加扣ち5-FU 動注群におい ては一次治療のみで制御されたもりが多かつたため，上 影全摘出術の例数が少々なつたのである。一方他剂動注 群での一次治療上上顎全摘出術上の役割はほほ等しく， 照射単独群での雨者の比較では，上顎全摘出術の役割が 大きくなっている。

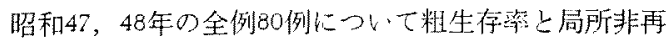




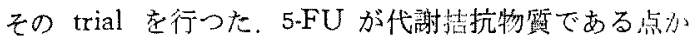

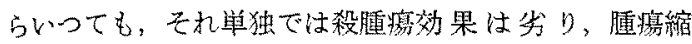
小はみられても，投薬をとめれば再び增大し，Howe ( $^{\text {) }}$ Latourette および Vurmund ${ }^{15}$ は生存率向上に注等与し ないと報告している。

5-FU が代謝搭抗凨として放射線堌感效果を表わすた め心恃続的に一定濃度の 5-FU 在作用さ吖る必要があ

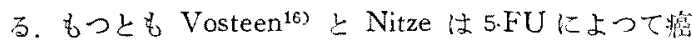
細胞の緗胞周期妾同期 (Synchronisation)させうるこし ている，その投与法は 5-FU $1000 \mathrm{mg}$ を $5 \%$ ブド一糖液

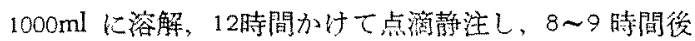
に照射する，著者たちも上颚洞癌に対する 5-FU 持続動 注に際し，照射前 8 時間に注入を中断し，照射後再び注 入虑始めることを試みたが，とくに著効を見ることはで きなかつた，一時注入を中断することによるトラブルも 軽視できないので，その徭は従来ど扔り24洔問持続注人 を行っている.

5-FU の副作朋として胃腸障害，口内炎，霄腸出血， 下㾥，白血球減少，皮膚炎，脱毛などがあるが，投与妾 中止寸れ枯回復するので大きな危䧃性はない，動注に上 って投与した場合，注入領域の反応は強く，とくに照射
部位は一層高度となるが，全身障害を来した症例はな い. 前述のように現在の上ころ必要十分な 5-FU 量とし て2000mg 考えている.

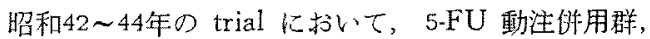
他刻動注併用群, 照射単独群の順に一次治㙩の成績が上 く，上影全摘出術の占的る役割が少なくなつている。し 加し上颚全摘出術に上る制御はいつうれの群に扔いても䄪 20\%であり，2 年以後はほぼ不変と見做すことができ る。一方一次治療による制御の䒰は $2 \sim 3$ 年まで流著明 であるが $4 \sim 5$ 年の遠隔成績では渐次，その差が少く なっている。こ机は 5.FU 動注併用群において4〜5年 後に再発し, 手術夌行い得なかつたもの, 脳出血, 骨㭪道 炎など他の死因による死亡例があつたことなどが原因と 考えられ，悪性腫瘍の治㙩成績を長期にわたつて间上さ せることの難かしさ在示している。

昭和47，48年の trial に批いては 5-FU 動注は一定と

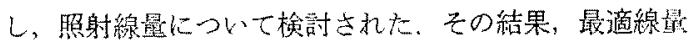
上して $5000 \mathrm{rad} / 25$ 回 $/ 5$ 週が求められた。 事た同時期に

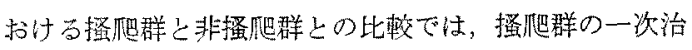
療成續が良く，形態上譏能索保存寸る锶点に立つ時，そ の意義が大きく評価される。しかし搔肥群の二次治療上

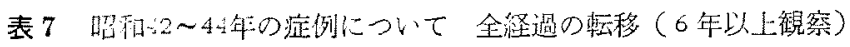

\begin{tabular}{|c|c|c|c|c|c|c|c|c|c|}
\hline & $\begin{array}{l}\text { 5-FU 動 注 } \\
\text { 侻 用 }\end{array}$ & $\begin{array}{c}\text { 他剒勘 注 } \\
\text { 群 }\end{array}$ & 照 & 独 & 射 & $\begin{array}{l}\text { trial } \\
\text { 除 }\end{array}$ & $\begin{array}{l}\text { 名 } \\
\text { 外 }\end{array}$ & 埕 & 例 \\
\hline & 25 & 35 & \multicolumn{3}{|c|}{45} & \multicolumn{2}{|r|}{25} & \multicolumn{2}{|l|}{130} \\
\hline 部 鼻 移 & 5 & 6 & \multicolumn{3}{|c|}{6} & \multicolumn{2}{|r|}{7} & 24 & $18.5 \%$ \\
\hline & 6 & 4 & & 4 & & & 3 & 10 & $12.3 \%$ \\
\hline
\end{tabular}

数字注症例数，（）中は原発㮺法制御されていた症例

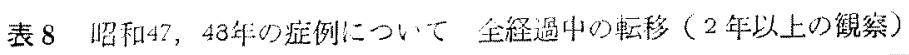

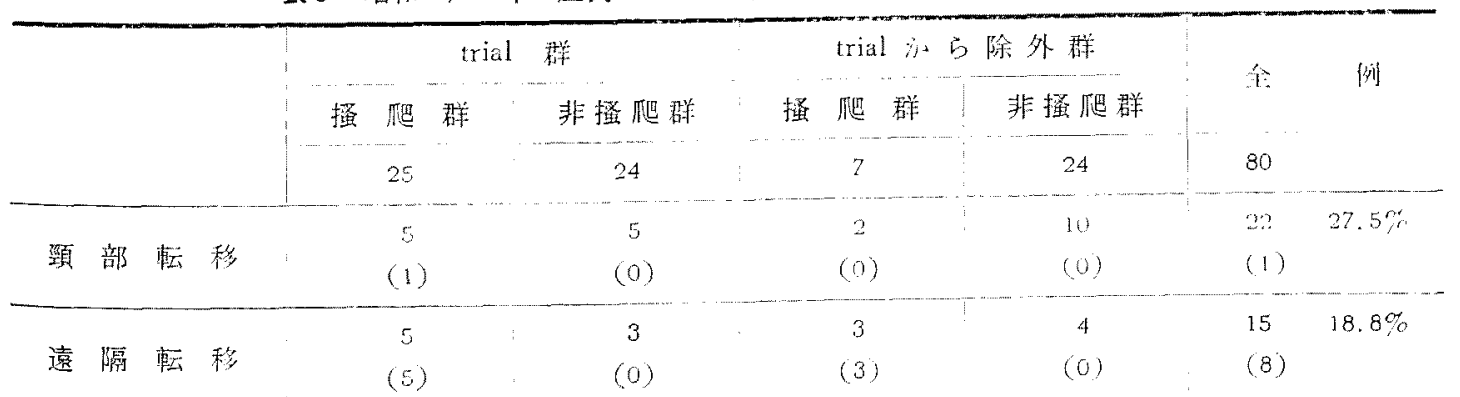

数宇は症例数，（）山は原発背は制御されていた症例 
して行つた上顎全摘出術の成績は瑟く，全例として見た 粗生存率ないし局所制御率はなお不満足なものであつ た

掻爬群の粗生存率を押えている因子に遠隔転移があ 亏。すなわち提爬術を含む一次治療後，局所が良く制御 されているにもか加わらず，頸部転移ないし遠隔転移を 見た症例䘮数えると非搔爬群に比し，また昭和 $42 \sim 44$ 年 群に比し多い傾向が見ら礼る(表 7, 表 8)。掻爬群25例 について頸部転移の1例と遠隔転移の 5 例では局所再発

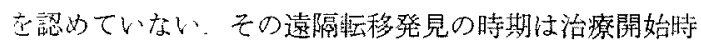
上り数えて，4力月， 7 力月， 10 力月， 1 年 3 ケ月， 1 年9ケ月であつた。东た昭和 47,48 年の trial 除外群の うち，搔爬を行つた７例中，局所再発なく遠隔転移を見 たものが 3 例あり，掻爬術が遠隔転移に対し誘発的に働 らいだ可能性は否定できないこれらの症例はいゔれも 放射線感受性が高く，末分化型の組織像であつたことか ら，今後は一次治療に打いて著効を示卞症例では搔爬術 は不必要であるばかりでなく，転移誘発の恐れもあるの で吸引清掃にとどめるべきである。

1つの trial 群に拁いて良い成績が得られる上，その 方法を次の時期においては全症例におよぼし，全症例と しての治療成績向上をはからねばならない，全症例の治 療成績が向上した時，はじめてその治療方針の正当性が 評洒され，定着したものとなる。その意味から，ある時 期に治療された全症例の成績の梌討が不可欠である。本 論文に扮いても前の時期に行われた 5-FU 動注併用群の 成績が良いことが判つたが，僅か25例であるため，全体 の成績向上に資することはできないそこで後の時期に あっては trial 群はもちろん，その除外群にもなる心゙く 5-FU 動注䘮行い，全症例80例中63例（29\%) に5-FU 動注が行われた，その結果全体上しての成續向上が見ら れ，初期の目的をほぼ澾したものと考えられる。

結論として，上顎洞癌に対する最善の治療方針は ${ }^{6 !} \mathrm{Co}$ て線に上る照射第一着手上し，照射開始上同時に5.FU の持続動注索始的万。照射線量は 5000rad/25回/5 週, 5-FU 総量は $2000 \mathrm{mg} / 4$ 週を原則上する。顎洞開放に 上り，洞内の壞死組織志吸引除去し，照射なかばにおい て肉腿的心認められる腫瘳老搔爬し，場合によつては Denker 式手術交行う，搔爬術を照射終了㨁後に再び行 うこともある，ただし，組織像が低分化性で，放射線感 受性多高、場合は搔爬術は行かない，以後は観察起続 け，再発老確認寸れば事情の許すかぎり上顎全摘出術を 行うさもなけ机は腔内照射あるいは外部照射老行う。

\section{結語}

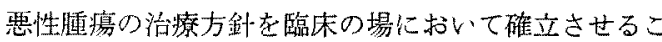
とは目下の急務であるが，非常に困難な問題でもある。 とくに上顥洞癁については，その最適の組台せによる併 用蹽法が各機闒で探求されているが，いずれの発表を見 ても症例数が少なく, randomized study が行われてい るものは稀である. randomized study の妥当性につい てはな㧍問題なしとはいえないが，慎重に立案されたも のによつて実施される限り，もつとも有用な方法と考え られる，それはある程度画一的治療となるが，予め定め られた症例について，予め定められた時期に限つて適用 されるるのであるため，個々の患者についての配虑が無 視されているわけではない。

教発的に治療された症例の retrospective study に続 いて, 副画的に症例割付索行つた prospective study が

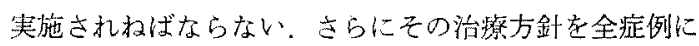

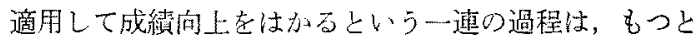
も着奉な道であるといつても過言ではない，著者たらは 昭和42年以来現在に至るまで，この方法論で進み，一応 の成果をあげることがでさた，その前途はなお楽観索許 さないが，今後もより良い治療方針索探求して着実な歩 办妾続けたい。

上䫑洞癌上いう数少い疾患を対象としているので，今 後は数機関が势力して1つの trial 実施できることを 念願している．そのような協力体制を通じて互の意志を 統一して trial 淮めれ代，より信頼性の高い成續が得 られ，さらに治療技術の向上と定着にも凟するものと考 えている。

\section{参考文献}

1) Currei, A.R.: Clinical studies with 5-fluoroural, Cancer Res. 18 ; 478, 1958.

2) Duschinsky, R.: The synthesis of 5-fuoropyrimidime, J.A.C.S. $79 ; 4599,1957$.

3) Heiderberger, C.: Fluorinated pyrimidines, A new class of tumor inhibitory compounds, Nature 179 ; 663. 1957

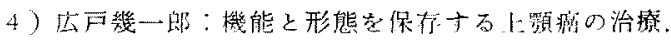
早鵕，18:238-245, $1972($ 昭47).

5) Howe, C.D.: Combined 5-fluorouracil and cobalt irradiation evaluated by double blind technique, Acta Univ. Inter. Contra Canc. 20; 400, 1964.

6) Jessc, R.H.: Combined intraarterial infusion and radiotherapy for treatment of advanced cancer of 
the head and neck, Front. Rad. Ther. Onc. 4;126$131,1969$.

7) Mukhejee, K.L.: Studies on fluorinated pyrimidines, XVI. Metabolism of 5-fluorouracil-2. $\mathrm{C}^{14}$ and 5 fluoro-2'-deoxyuridine-2-C $\mathrm{C}^{14}$, Cancer Res. $23 ; 49-66$, 1963.

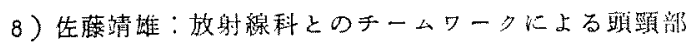

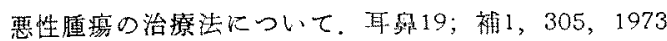
(昭48).

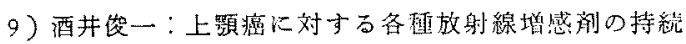
動注療法。耳县臨床63；941-952，1970（昭44).

10）酒茾俊一：上頻癌，金原出版1974（昭49).

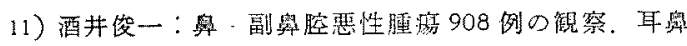
$21 ; 859-884,1975$ (昭50).

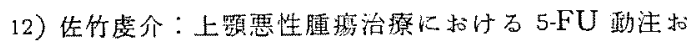
よび照射の效とその適量について。耳鼠19；121-126， 1973 (昭48).

13) Shaw', H.J.: Combined therapy for cancer of the upper jaw and paranasal sinuses, J. Laryng. Rhinol. $80 ; 105-124,1966$.

14) Shigematsu, S.: Recent trials in the treatment of maxillary sinus carcinona, with special reference to the chemical potentiation of radiation therapy. Acta Oto-laryng. (Stockh.) $71 ; 63-70,1971$.

15) Vermand, H.: Clinical Studies of 5-fuorouracil as ajuvant to radiotherapy, Front. Rad. Ther. Onc. $4 ; 132-158,1969$.

16) Vosteen, K.H.: Die Strahlenbehandlung maligner Tumoren nach Synchronisation des Zellteilungsrhythmus, Strahlentherapie 143;329 337, 1972.

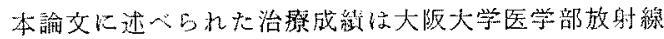
料治療グルーブとの洪同研究に上るものでるる。ここに 深く謝意を表古。

(原稿受侧昭和50,12.19日) 